\title{
The association between anthropometric profiles and somatotype with 100 meter sprint amongst Indonesian sprint athletes
}

\author{
DOI: https://doi.org/10.22435/hsji.v12i1.3155
}

Eddy Purnomo ${ }^{1}$, Novita Intan Arovah ${ }^{2}$, Alfonsia Purnamasari ${ }^{2}$

${ }^{1}$ Faculty of Sport Science, Yogyakarta State University, Indonesia

${ }^{2}$ Department of Pharmacy, Pelita Harapan University, Indonesia

Corresponding author: Eddy Purnomo

Email: eddy_purnomo@uny.ac.id

Received: April 29, 2021; Revised: Februari 23, 2021; Accepted: May 31, 2021.

\begin{abstract}
Background: One hundred meter sprint was influenced by various internal and external factors. Somatotype and anthropometry profiles are possibly to be one of the factors that predicts performance. The aims of this study were to assess the anthropometry and somatotype profiles obtained from an example of Indonesian team university male sprinters and to elucidated potential correlations between anthropometry profile and somatotype with the $100 \mathrm{~m}$ sprint.

Method: It was recorded that 20 selected sprint athletes participated as representatives from Indonesia in the XVIII ASEAN University Games with an averaged age (20.0 \pm 0.92 year old). Anthropometric assessment includes height, weight, skinfold (triceps, supra-spinale, subscapula, suprailiaca, abdomen, calf, front thigh and chest)), two bicondylar widths (humerus and femur) and two circumferences (biceps and femur). The somatotype assessment was based on the Health \& Carter method. Body fat percentage was assessed using the equation determined by Berzerk et al. (1963). Body Mass Index is calculated from body mass divided by height squared $(\mathrm{kg} / \mathrm{m} 2)$. Multicorrelation matrix and simple linear regression were used to assess the potential correlation between somatotype profile and anthropometry with the $100 \mathrm{~m}$ sprint.
\end{abstract}

Result: The average value of ectomorph-mesomorph-endomorph was 3.40-4.08-0.84 BMI at 20.6 0.6, while the fat percentage was $9.2 \pm 0.8$. There were no significant correlation and regression slope found between somatotype profile and anthropometry with the $100 \mathrm{~m}$ sprint.

Conclusion: Most of the athletes representing Indonesia at the ASEAN University Games were mesomorphs and ectomorphs. They had low endomorph score fat percentage. Body shape requirements was not related to the $100 \mathrm{~m}$ sprint. Further investigation is recommended to amplify the findings.

(Health Science Journal of Indonesia 2021;12(1):26-32)

Keyword: body composition, somatotype, sprinter

\begin{abstract}
Abstrak
Latar belakang: Lari seratus meter dipengaruhi oleh berbagai faktor internal dan eksternal. Profil somatotipe dan antropometri diperkirakan merupakan salah satu diantara faktor yang dapat memprediksi kinerja. Tujuan dari penelitian ini adalah untuk menilai antropometri dan somatotipe yang diperoleh dari sampel pelari putra perguruan tinggi Indonesia dan menjelaskan potensi korelasi antara antropometri dan somatotype dengan lari 100 meter.
\end{abstract}

Metode: Tercatat 20 atlet sprinter terpilih sebagai perwakilan dari Indonesia di ASEAN University Games XVIII dengan rata-rata umur (20.0+0.92 tahun). Penilaian antropometri meliputi tinggi, berat badan, lipatan kulit (trisep, supra-spinale, subskapula, suprailiaka, abdomen, betis, paha depan dan dada), dua lebar bicondylar (humerus dan femur) dan dua lingkar (bisep dan femur). Penliaian somatotipe didasarkan dari metode Heath \& Carter. Presentasi lemak tubuh dinilai sebagai persamaan yang ditentukan oleh Berzerk et al. (1963). Indeks Masa Tubuh dihitung dari masa tubuh yang dibagi dengan tinggi badan kuadrat $(\mathrm{kg} / \mathrm{m} 2)$. Matrix multikorelasi dan regresi linear sederhana digunakan untuk menilai potensi korelasi antara profil somatotipe dan antropometri dengan lari cepat $100 \mathrm{~m}$.

Hasil: Rata-rata nilai ectomorph-mesomorph-endomorph adalah 3.40-4.08-0.84. BMI di angka 20.6+0.6, sedangkan presentasi lemak di angka 9.2 \pm 0.8 . Tidak ada korelasi yang signifikan dan kemiringan regresi ditemukan antara somatotipe dan antropometri dengan lari $100 \mathrm{~m}$.

Kesimpulan: Atlet yang mewakili Indonesia di ASEAN University Games sebagian besar mesomorph and ectomorph. Mereka memiliki presentasi lemak skor endomorph rendah. Syarat-syarat bentuk tubuh tidak berkaitan dengan lari $100 \mathrm{~m}$. Investigasi lebih lanjut direkomendasikan untuk memperkuat temuan.

(Health Science Journal of Indonesia 2021;12(1):26-32)

Kata kunci: antropometri, somatotipe, pelari 
The physical profile of athletes, both athletes in team sports and individual sports, needs to be possessed by each parent sport, especially athletes who always won in each sport at the national, regional and international level. When it is evaluated based on the achievements, especially measurable sports, in this case athletic especially sprint, the progress is increasing. This can be seen from the time records recorded. For example the $100 \mathrm{~m}$ world men's sprint athlete reached 9.69 seconds, while the Indonesian sprint athlete reached only 10.13 seconds. This showed that the development of beginner, junior and senior athletes was going well. However, not many sports researchers are consistent with performancerelated research. As we know, there is no record on the results of measuring the physical profile/physical characteristics, in this case the athlete's somatotype, especially the national sprint athlete. For example, Indonesian sprint athlete, Muhamad Zohri who is only 20 year old. Therefore, it needs to be executed by sports experts or sprint trainers.

Somatotype is a state quantification description of an individual athlete morphological status. As a description, the quantification will be the size of human body from the numbers 0.5 to 12 . Somatotype classifies the human body into three basic components, Endomorph, Mesomoprh and Ectomorph. ${ }^{1,10}$

The difference between these three components lies in the state of fat and muscle. The endomorph represents an individual athlete's fat and number of fat, mesomorph describes the state of strong muscles, while ectomorph describes the state of lean muscles.

There are many events contested in track and field sports, such as running, jumping and throwing. However, each of these event requires a different body shape and physical characteristics. When viewed from the physical characteristics (stature) of a sprint athlete, it is clearly different when comparing long-distance runners to throwers, but it will be the same or almost the same for jumpers to jumpers. Sprint athletes are more muscular (hypertopic) in the buttocks (gluteal muscles) and chest-shoulders compared to long-distance runners who are much thinner/slimmer (thinner) and less muscular than sprint athlete. ${ }^{2,3,6}$

Furthermore, the authors conducted further research on the state of body composition and physical characteristics of Indonesian student sprint athletes who were prepared to participate in the $18^{\text {th }}$ ASEAN University games in Singapore on 2016. The reason of conducting the research is that there was no data on anthropometric measurements and body composition of Indonesian student sprint athletes.

Therefore, measurement and understanding of physical characteristics, in this case the basic morphology of an athlete, is the basis on which a training process can be built. So that the coach will easily and quickly predict or select the sport to be fostered in the future. Thus, specific anthropometric characteristics are needed to be successful in certain sport event. In addition, it should also be noted that there are several differences in body structure and body composition of sprint athletes, both for distances of $100 \mathrm{~m}, 400 \mathrm{~m}, 110 \mathrm{~m}$ hurdles and 400 $\mathrm{m}$ hurdles which are very specific; It is different for long-distance running, jumping and throwing athletes. Thus, the requirements of the physical form or body of each sport leads to the selection of the most suitable body type for sports that can later achieve maximum performance, known as "Morphological Optimization".,2,5

Therefore, as a sprint athlete trainer, you should understand how the athlete was being coached both in terms of physicality and body composition. Thus, the purpose of this research is to study the physical picture/body shape, in this case the somatotype and body composition of Indonesian student sprint athletes at a training center in Jakarta. And this is a picture of Indonesian sprint athletes today.

\section{METHODS}

This research was conducted in Jakarta at the training camp during preparation for ASEAN University Games held on 15 to 20 July 2016 in Singapore.

\section{Study design and population}

A cross-sectional study was conducted in the health room of the Jakarta Madya Stadium on June 2016 to the student sprint athletes who would be prepared for the ASEAN University Games. Population in this survey was 120 student athletes from all over Indonesia who were participating in the national training camp during preparation for the Asean University Games. The average age of athletes were between 20 and 22 years old, 50 female athletes and 70 male athletes. Especially for sprint athletes there were 30 participants consisting of 20 male athletes and 10 female athletes. Furthermore, the sampling technique in this study was purposive sampling, 
namely all sprint athletes at the national training center preparation for the ASEAN University Games Singapore, totaling 20 samples. The inclusion criteria for the research sample were male athletes who joined the ASEAN University team in 2016, participated in running events, $100 \mathrm{~m}, 200 \mathrm{~m}, 400 \mathrm{~m}$, $4 \times 400 \mathrm{~m}, 4 \times 100 \mathrm{~m}, 110 \mathrm{~m}$ hurdles or $400 \mathrm{~m}$ hurdles. While exclusion criteria are all male and female athletes from ASEAN University team representing all sports including long and middle distance.

\section{Data collection and variable}

Anthropometrical measurements:

Seven morphological body measures taken were: height, weight, body mass indexs, Humerus breadth, Femur breadth, Arm girth, Calf girth and eight folds of skin: triceps, supra-spinale, subscapula, suprailiaca, abdomen, calf, front thigh and chest. The height was measured using stadiometry to the nearest $0.5 \mathrm{~cm}$ and a bathroom scale was used to measure body mass to the nearest $0.1 \mathrm{~kg}$.

This method is implemented for somatotype assessment with the equation used as follows:

Endomorphy $=-0.7182+0.1451 \times \Sigma \mathrm{SF}-0.00068$ $\times \Sigma \mathrm{SF}^{2}+0.0000014 \times \Sigma \mathrm{SF}^{3}$ where $\Sigma \mathrm{SF}=($ sum of triceps, subscapular and supraspinale skinfolds) multiplied by (170.18/height in $\mathrm{cm})$. This was called height-corrected endomorphy and was preferred method for calculating endomorphy).

Mesomorphy $=0.858 \times$ humerus breadth $+0.601 \times$ femur breadth $+0.188 \times$ corrected arm girth +0.161 $\times$ corrected calf girth - height $\times 0.131+4.5$

Three different equations were used to calculate ectomorphy according to the Height -Weight Ratio (HWR): If HWR was greater than or equal to 40.75 then, Ectomorphy $=0.732 \times \mathrm{HWR}-28.58$. If HWR was less than 40.75 and greater than 38.25 then, Ectomorphy $=0.463 \times \mathrm{HWR}-17.63$. If HWR was equal to or less than 38.25 then, Ectomorphy $=0.1$

Body Fat $\%$ : Body Fat $\%$ was calculated using the equation of Siri (1956). Durnin and Womersley (1974) technique was for calculating Body density. Body Fat $\%=(495 /$ Body density $)-450$. Body Density or BD $(\mathrm{gm} / \mathrm{cc})=1,089733-0,0009245$ $\left(\sum \mathrm{ABC}\right)+0,0000025\left(\sum \mathrm{ABC}\right)^{2}-0,000079 \mathrm{x}$ age

Where:(A) = triceps Skinfold
(B) = Suprailliaca skinfold and

(C) = Abdomen (larry G.Shaver 1982)

Lean Body Weight or LBW $(\mathrm{kg})=($ Total Body Weight - Total Weight of Fat)

Total Weight of Fat $=($ Weight $\mathrm{x}$ percent of fat $) / 100$

BMI $(\mathrm{Kg} / \mathrm{m} 2)=($ Body mass in $\mathrm{Kg}) /($ Stature in Meters) ${ }^{2}$., (Meltzer et al., 1988)

Ideal Body Mass $=($ Height -100$)-10 \%($ Height- 100$)$

Lean Body Mass $=100 \%-$ TWF $\%{ }^{6,11}$.

The dependent variable is university sprint athleres who represented universities in national or regional competitions at both Japan and Indonesia. While the independent variable is a variable related to body composition and somatotype characteristics of sprint athletes. Furthermore, the variable explanation can be seen in Table 3 .

\section{Data Analysis}

Descriptive analysis of the variables were carried out with central trend (mean), dispersion data (standard deviation), kurtosis and skewness. Kurtosis and skewness were used to assess the shape of the distribution. To see the normality of the data was to look at Kurtosis and Skewness divided by the standard error and the resulting values of -1.96 and 1.96 , this was considered sufficient to establish normality of the data. Age and anthropometric assessment were conducted along with the $100 \mathrm{~m}$ sprint performance (time in seconds). Multi-correlation matrix among anthropometric profiles and anaerobic performance (100 m sprint performance) based on Pearson correlation was used mainly to assess the association as well as simple linear regression between $100 \mathrm{~m}$ performance and the anthropometric measures. Data were analyzed using SPSS ${ }^{\circledR}$ version 25 (IBM Corporation, Armonk, NY, USA). The significant level for all studied variables was fixed at $\mathrm{P}<0.05$, where the mean was more than the mode value.

\section{RESULTS}

Table 1 illustrates age, anthropometric profile and the $100 \mathrm{~m}$ running performance of all athletes. As seen in Table 1, the mean age was $20.08 \pm 0.92$ years. All participants were considered as normal weight under the Asian body mass index criteria. They were also 
considered as lean to normal based on fat percentage criteria within their age range. The somatotype showed a dominant trend toward mesomorph with only small tendency toward endomorph. They had a small variability in the $100 \mathrm{~m}$ running performance $(\mathrm{SD}=0.08$ second) indicating that their anaerobic performance was relatively similar. The kurtosis and skewness of all variables indicated approximately normal distributed.

Table 2 summarises correlations among anthropometric profiles and the correlation with $100 \mathrm{~m}$ running performance based on Pearson correlation. As seen in Table 2, there was no significant correlation found between all anthropometric profiles and 100 $\mathrm{m}$ running performance. As expected, significant negative correlations was found between ectomorph and body mass index $(\mathrm{r}=-0.84, \mathrm{p}<0.001)$, as well as between ectomorph and mesomorph $(\mathrm{r}=0.56, \mathrm{p}=$ 0.011 ). A positive correlation was found between mesomorph and endomorph $(\mathrm{r}=0.90, \mathrm{p}<0.001)$

Table 1. Anthropometric parameters and $100 \mathrm{~m}$ running time of sprinters $(n=20)$

\begin{tabular}{|c|c|c|c|c|c|c|}
\hline Variables & Minimum & Maximum & Mean & Std. Deviation & Skewness & Kurtosis \\
\hline Age(year) & 19.00 & 22.10 & 20.08 & 0.92 & 0.93 & 0.32 \\
\hline Height $(\mathrm{cm})$ & 166.60 & 178.50 & 171.37 & 3.02 & 0.75 & 0.26 \\
\hline Weight (kg) & 56.00 & 66.00 & 60.54 & 2.62 & 0.42 & -0.22 \\
\hline Body mass index $(\mathrm{kg} / \mathrm{m} 2)$ & 19.61 & 22.28 & 20.61 & 0.55 & 1.32 & 3.80 \\
\hline Humerus breadth $(\mathrm{cm})$ & 6.40 & 7.50 & 6.83 & 0.29 & 0.63 & 0.12 \\
\hline Femur breadth $(\mathrm{cm})$ & 8.70 & 10.60 & 9.40 & 0.56 & 0.83 & -0.49 \\
\hline Arm girth $(\mathrm{cm})$ & 32.00 & 36.00 & 33.93 & 1.28 & -0.23 & -1.17 \\
\hline Calf girth $(\mathrm{cm})$ & 35.50 & 45.00 & 40.34 & 1.95 & -0.15 & 1.95 \\
\hline Triceps (mm) & 6.50 & 9.10 & 7.82 & 0.72 & 0.41 & -0.33 \\
\hline Supra-spinale (mm) & 6.30 & 8.60 & 7.27 & 0.68 & 0.70 & -0.07 \\
\hline Subscapula (mm) & 7.00 & 10.20 & 8.77 & 0.70 & -0.23 & 1.58 \\
\hline Suprailiaca (mm) & 8.70 & 13.80 & 11.38 & 1.48 & -0.33 & -0.73 \\
\hline Abdomen (mm) & 14.20 & 16.50 & 15.52 & 0.68 & -0.37 & -1.13 \\
\hline Calf (mm) & 4.50 & 6.60 & 5.60 & 0.61 & 0.25 & -0.93 \\
\hline Front thigh (mm) & 7.50 & 12.50 & 9.58 & 1.35 & 0.69 & -0.17 \\
\hline Chest (mm) & 10.60 & 15.80 & 13.33 & 1.42 & 0.07 & -0.39 \\
\hline Fat $(\%)$ & 7.67 & 10.70 & 9.15 & 0.82 & 0.30 & -0.23 \\
\hline Endomorph & 0.71 & 0.94 & 0.84 & 0.06 & -0.42 & -0.17 \\
\hline Mesomorph & 2.84 & 4.92 & 4.08 & 0.57 & -0.60 & 0.09 \\
\hline Ectomorph & 2.44 & 3.92 & 3.40 & 0.34 & -1.12 & 2.21 \\
\hline $100 \mathrm{~m}$ running time (seconds) & 10.60 & 10.90 & 10.79 & 0.08 & -0.28 & -0.32 \\
\hline
\end{tabular}

Table 2. Multicorrelation matrix among anthropometric profiles with $100 \mathrm{~m}$ running time performance

\begin{tabular}{lllllll}
\hline & BMI & \% Fat & Endomorph & Mesomorph & Ectomorph & 100 m-run time \\
\hline BMI & 1.00 & & & & & \\
\% Fat & -0.44 & 1.00 & & & & \\
Endomorph & -0.04 & -0.20 & 1.00 & 1.00 & 1.00 & 0.10 \\
Mesomorph & 0.40 & -0.37 & $0.90^{*}$ & $-0.56^{*}$ & -0.13 & 0.10 \\
Ectomorph & $-0.84^{*}$ & 0.40 & -0.18 & -0.09 & & \\
\hline
\end{tabular}


Figure 1 further illustrates the scatter plots and regression slope between anthropometric profiles and the $100 \mathrm{~m}$ running time. Consistent with the finding in Table 2 and as seen in Figure 1, there was no significant regression slope found among relation between anthropometric profiles and $100 \mathrm{~m}$ running time.

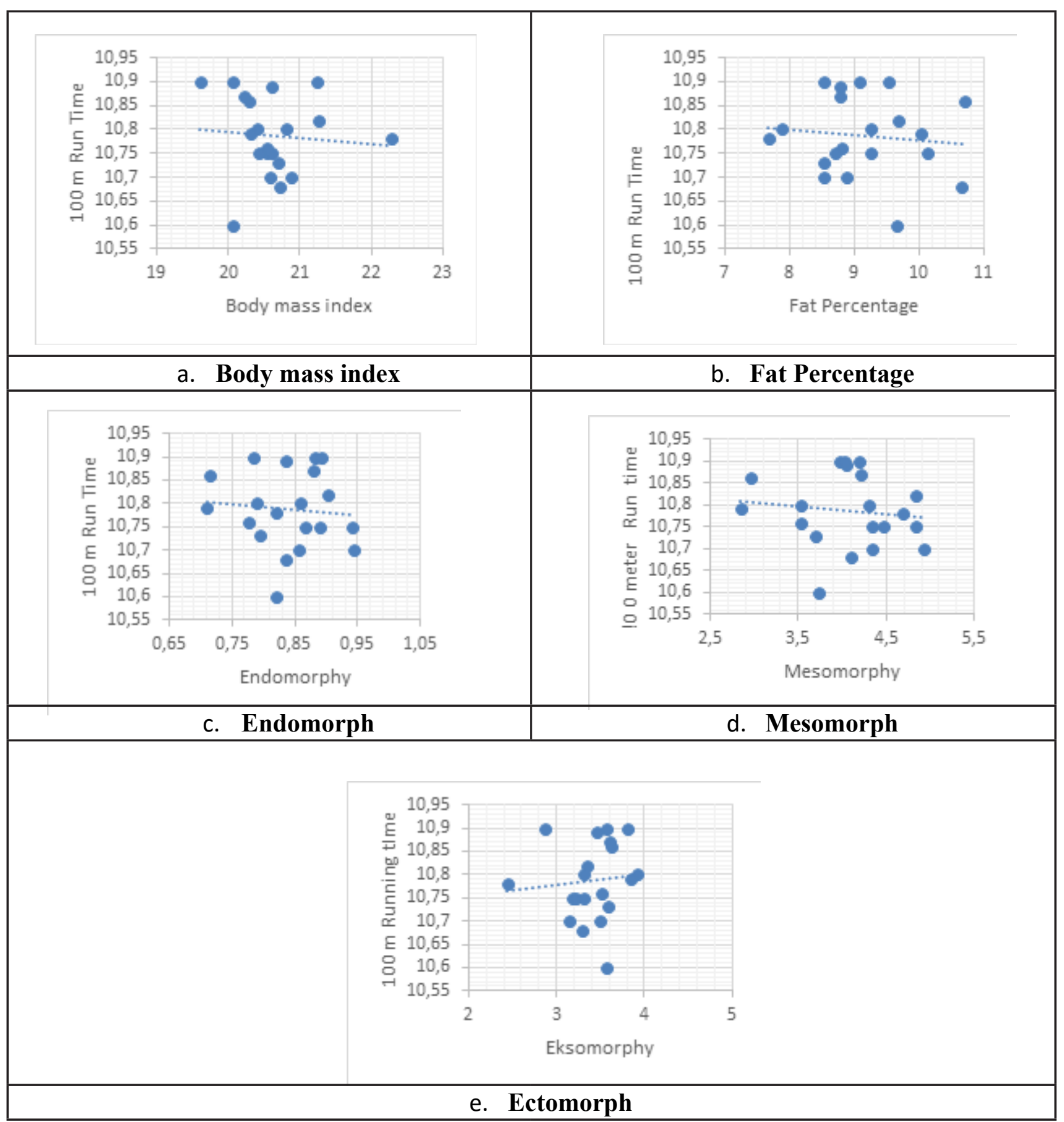

Figure 1. Scatter Plot between Anthropometric Profiles and $100 \mathrm{~m}$ Running Performance 


\section{DISCUSSION}

To the best of our knowledge, this study is the first to assess the anthropometric characteristics of sprint athletes representing Indonesia in regional competition event and to assess their potential relation to $100 \mathrm{~m}$ running performance among Indonesian sprint athletes, with a small sample, since the number of student-athletes selected to represent Indonesia was only 20 paraticipants.

Consistent with previous findings we found that our participants were predominantly mesomorph and ectomorph with low endomorph scores. Our participants also presented normal BMI based on Asian standard and low-fat percentage. The average somatotype values of the athletes in our study were 3.40-4.08-0.84 (ectomorph-mesomorphendomorph). The endomorph value was, however, lower than those reported from Croatian sprint athletes with 2.1-5.0 -2.6. ${ }^{1}$ The endomorph was also lower than those reported in amateurs athletes from Indian junior athletes with 2.53- 4.31-3.06, ${ }^{2}$ as well as those reported from Japanese junior sprint athletes (2.47-3.77-3.11) and Indonesian amateurs (2.394.86-2.79). ${ }^{3}$ To be noted that the performance of our sprint athlete was higher $(10.79 \pm 0.08$ second $)$ than those reported from the study in Croatia $(11.33 \pm 0.53$ second), while there was no running performance reported from the study in India, Indonesia and Japan. Apart from the difference in athletic ability explaining the difference of somatotype, the difference in race and age range may explain the diversity.

During the $100 \mathrm{~m}$ sprint event, myriad physiological and anatomical factors determined athletic performance through phases such as acceleration (0-30m), maximum velocity, (30-60m) and speed maintenance (60-100m) ${ }^{4,9,14,17,18}$ The factors include stride length, velocity or speed, energy production, as well as power. ${ }^{4}$ The other two important anatomical predictors of $100 \mathrm{~m}$ running performance were anthropometry and somatotype. Anthropometry characteristic may affect sprint performance, as it may affect stride rate, thus taller athletes might be preferred. ${ }^{5,715}$ Meanwhile, somatotype assesses body shape and it is rated from 1 to 7 on endomorph (roundness), mesomorph (muscularity) and ectomorph (leanness). ${ }^{6,13,14}$ A growing body of evidence suggests that $100 \mathrm{~m}$ athletes should be high in mesomorph, low in ectomorph and endomorph. ${ }^{7,8,12}$
The anthropometric profile and the somatotype components in our study, however, were not related to their performance in $100 \mathrm{~m}$ sprint. The findings were in discrepancy. It was reported findings from previous studies that mesomorph was positively associated while ectomorph was negatively correlated with 100 $\mathrm{m}$ sprint performance. ${ }^{6}$ The study also suggested that lower rates in endomorph and higher rates in ectomorph would be resulted in significantly better race performance. The discrepancies might be due to the lack of heterogeneity of $100 \mathrm{~m}$ performance in our samples. The differences also could be due to the difference in the race as previous studies conducted amongst Caucasians. Further investigations thus are required to confirm our findings with more heterogeneous samples.

In conclusion, our findings indicated that Indonesian university sprint athletes were predominantly mesomorph and ectomorph with low endomorph score as well as low-fat percentage. The anthropometric profile and the somatotype components, however, were not related to their performance in $100 \mathrm{~m}$ sprint. Further studies with more heterogeneous samples are recommended to confirm the findings.

\section{Acknowledgment}

The author would like to thank PBPASI and DIRMAWA who have given confidence to the author as a team manager and coach of the Indonesian athletic team at the ASEAN University Games, especially to Muhamad Hasan as Chairman of PBPASI who has support a lot in terms of material and substance in writing this journal.

\section{REFERENCES}

1. Barbieri D, Zaccagni L, Babić V, Rakovac M, MišigojDuraković M, Gualdi-Russo E. Body composition and size in sprint athletes. The Journal of Sports Medicine and Physical Fitness. 2017;57(9):1142.

2. Sukanta Saha. Somatotype and body composition characteristics of Indian university level football players. World Applied Sciences Journal; 2017;35(3):356-60.

3. Lees M, Oldroyd B, Jones B, Brightmore A, O’Hara JP, Barlow MJ, et al. Three-compartment body composition changes in professional rugby union players over one competitive season: a team and individualized approach. J. Clin. Densitom. 2017; 20:50-7.

4. Dwi DRAS, Asmawi M, Wasan A, Widiastuti W. Pengaruh metode latihan dan power tungkai terhadap 
peningkatan kecepatan akselerasi sprint. JUARA: Jurnal Olahraga. 2018;3(2):62-9. Indonesian.

5. Campa F, Semprini G, Júdice PB, Messina G, Toselli S. Anthropometry, physical and movement features, and repeated-sprint ability in soccer players. International Journal of Sports Medicine. 2019;40(02):100-9.

6. Heath BH, Carter JL. A modified somatotype method. American Journal of Physical Anthropology. 1967;27(1):57-74.

7. Ryan-Stewart H, Faulkner J, Jobson S. The influence of somatotype on anaerobic performance. PloS one. 2018;13(5):e0197761.

8. Chaouachi M, Chaouachi A, Chamari K, Chtara M, Feki Y, Amri M, et al. Effects of dominant somatotype on aerobic capacity trainability. British Journal of Sports Medicine. 2005;39(12):954-9.

9. Buśko K, Lipińska M, Michalski R, Pastuszak A. Somatotype variables related to muscle torque and power output in female volleyball players. Acta Bioeng. Biomech. 2013;15(2): 119-26.

10. Carter JEL, Ackland TR, Kerr DA, Stapff AB. Somatotype and size of elite female basketball players. J. Sports Sci. 2005;23(10):1057-63.

11. Puja Pathak. Anthropometrics chracteristicc and somatotype of Bangali women migrated from Bangladesh and living in the slum areas near rail ways in West Bengal. International Journal of Science and Research Methodology. 2018;10(3): 230 - 6 .
12. Watts AS, Coleman I, Nevill A. The changing shape characteristics associated with success in worldclass sprinters. Journal of Sports Sciences. 2012; 30(11):1085-95.

13. Watts AS, Coleman I, Nevill A. Demographic characteristics of world class Jamaican sprinters. The ScientificWorld Journal . 2013;5-9. Article ID 670217.

14. Kruger A, Pienaar AE. Anthropometrical, physical, motor and sport psychological profile of adolescent males with sprinting potential. South African Journal for Research in Sport, Physical Education, and Recreation. 2016;38(3):81-93.

15. Lusiana. Faktor pengaruh kemampuan lemparan (shooting) pada atlet handball putri Jawa Tengah, JPEHS. 2015;2 (2):65-8. Indonesian.

16. Yamashita D, Asakura M, Ito Y. Physical characteristics and performance of Japanese top-level American football players. Journal of Strength and Conditioning Research. 2017 Sept ;31(9):2455-61.

17. Posthumus L, Macgregor C, Winwood P, Tout J, et al. The physical characteristics of elite female rugby union players. Int. J. Environ. Res. Public Health. 2020;17:6457.

18. Argus CK, Gill N, Keogh J, Hopkins WG, Beaven CM. Effects of a short-term pre-season training programme on the body composition and anaerobic performance of professional rugby union players. J. Sports Sci. 2010;28:679-86. 